\title{
EFFECT OF ARBUSCULAR MYCORRHIZAL FUNGI ON AN ECOLOGICAL CROP OF CHILI PEPPERS (Capsicum annuum L.)
}

\author{
Claudia Castillo R. ${ }^{*}$, Leonardo Sotomayor S. ${ }^{1}$, César Ortiz O. ${ }^{1}$, Gina Leonelli C. ${ }^{1}$, Fernando Borie B. ${ }^{2}$, \\ and Rosa Rubio H. ${ }^{2}$
}

\begin{abstract}
Mapuche farmers in southern Chile have been cultivating local ecotypes of chili pepper (Capsicum annuиm L.), called locally "Cacho de cabra", for many decades. It is used to make "merkén", a condiment that is consumed locally and exported. This vegetable requires a nursery stage and can obtain nutritional benefits from symbiotic associations such as mycorrhizal fungi, achieving a better adaptation to transplanting. Arbuscular mycorrhizal fungi (AMF) are obligate biotrophes appearing in abundance in agroecosystems with conservation management. The aim of this study was to compare effectiveness of two AMF, a commercial mycorrhizal inoculant (IC, Glomus intraradices) and another native (IN, Glomus claroideum) with a control without inoculation (-I) on the production and quality of "Cacho de cabra". At 45 days after sowing (DAS) transplanting was carried out and at 90 and 216 DAS fruit quality, fungal and edaphic parameters were evaluated. The harvest was at four stages. With IN inoculation plants and with greater foliar area were obtained. Also, precocity of fruit production was observed. The harvest started 49 days earlier and fresh weight was 177\% higher than that of the control. Root colonization was low, showing significant differences between IN and IC, while a large number of spores was produced in the substrate. It was concluded that inoculation with native fungi decreased transplanting stress thus accelerating the maturation stage of plants and resulting in higher and better yield quality.
\end{abstract}

Key words: mycorrhiza, inoculant, biofertilizers, fruit quality, vegetables.

\section{INTRODUCTION}

Mycorrhiza is a symbiotic relationship between arbuscular mycorrhizal fungi (AMF) and the roots of the majority of vascular plants. Through extensive root external mycelia networks the fungi improve the capture of relatively immobile nutrients such as $\mathrm{P}$ (Souchie et al., 2006), $\mathrm{Cu}$ and $\mathrm{Zn}$, as well as improving water absorption (Augé, 2004), capturing at the same time $\mathrm{C}$ fixed as hexose from the apoplast of the root cortical cells (Douds et al., 2005). However, not all AMF/plant combinations are compatible, with some fungi being more beneficial to a host and adapting themselves to determined edaphoclimatic

\footnotetext{
${ }^{1}$ Universidad Católica de Temuco, Facultad de Recursos Naturales, Casilla 15-D, Temuco, Chile.

*Corresponding author (ccastill@uct.cl).

${ }^{2}$ Universidad de La Frontera, Facultad de Ingeniería, Ciencias y Administración, Casilla 54-D, Temuco, Chile (fborie@ufro.cl). Trabajo presentado en LVIII Congreso Agronómico de Chile (2007) y VII Congreso Internacional de Recursos Naturales (2007).

Received: 10 March 2008.

Accepted: 17 June 2008.
}

conditions, showing marked structural and functional differences among species and even among morphotypes of the same fungal species (Linderman and Davis, 2004). To achieve a satisfactory inoculation effect it is necessary to known the compatibility between a determined host and the AMF, in order to select the appropriate fungal strain for the specific plant cultivar (Rodríguez et al., 2004).

AMF are important in ecological agriculture because of the benefits they provide to the majority of cultivars and the conservation of the environment by acting as biofertilizers, bioprotectors and biocontrol agents (AzcónAguilar et al., 2002). In the framework of a sustainable agriculture, that includes a more respectful management of the environment based on the sustainable use of resources, and taking advantage of strategies that nature itself employs for its self-regulation, the soil is considered as an active element of the system, composed of interrelated physical, chemical and biological factors, the AMF forming part of a biological microcosm (Jaizme-Vega and Rodríguez-Romero, 2004). Consequently, the design of any agricultural production system should consider the use of these microsymbionts as inseparable components 
of agro-ecosystems to carry out diverse functions in association with plants, among others, acting as biological substitutes for mineral fertilizers. This last case does not mean not to fertilize, but rather that fertilization can be more efficient, saving important quantities of mineral fertilizers, together with better absorption of nutrients available in the soil.

Vegetable crops that at their start require a nursery stage can benefit from AMF inoculation, among these chili peppers (Capsicum annuum L.). Consequently the use of AMF is being incorporated into horticultural practices (Evans, 1997). However, the efficiency of commercial inoculants currently in the market is unknown, with the possibility of confusing its action with that of nonmycorrhizal additives (Von Alten et al., 2002) that can increase plant growth and that is not due to mycorrhiza (Corkidi et al., 2005).

Around 5000 ha of chili peppers are cultivated annually in Chile, from the north to the central south of the country. The Araucanía Region offers favorable growth conditions, especially for local ecotypes that small-scale Mapuche farmers have been growing for decades. They are used mainly in the production of "merkén", an ancestral condiment made from ground, salted and smoked chili peppers. At a national level approximately $9000 \mathrm{t}$ of pepper are marketed each year. The variety "Cacho de cabra" accounts for approximately $1500 \mathrm{t}$, of which $3 \%$ to $6 \%$ is destined to the production of "merkén". Given the economic and cultural importance of this crop in the Araucanía Region, the objective of this study was to compare the effects of inoculation of two species of AMF, one commercial (Glomus intraradices) and the other native (Glomus claroideum), with a control without inoculation (-I), on the yield and quality of chili peppers grown under greenhouse conditions.

\section{MATERIALS AND METHODS}

Seed for bioassays was sown in January 2007 in greenhouses of the Universidad de La Frontera; at 45 days after seeding (DAS) the seedlings were transplanted. The harvest was carried out in four stages (at 167, 189, 203 and 216 DAS), finishing in July of the same year.

\section{Bioassay}

For the seeding stage, $250 \mathrm{~mL}$ pots were used with an Ultisol soil from the area of Purén $\left(38^{\circ} 40^{\prime} \mathrm{S}, 73^{\circ} 00^{\prime} \mathrm{W}\right)$. The soil had been used for cultivation of peppers by smallscale mapuche farmers for several years. The Ultisol was mixed with sand and vermiculite (ratio 7:2.5:0.5), vapor sterilized for $1 \mathrm{~h}$ for 3 consecutive days to eliminate native AMF (Table 1).

Two types of AMF inoculants were used: a native species, G. claroideum (IN), and the other a commercial, $G$. intraradices (IC). The equivalent of $20 \mathrm{~mL}$ of solid inoculants was added to each experimental unit, using the same substrate without inoculation as a control (-I). Two disinfected and pre-germinated pepper seeds from local ecotypes were planted in each pot and covered with the same substrate. A completely random design was used, with 40 replications, with a total of 120 experimental units that were kept under greenhouse conditions, with controlled lighting, temperature and humidity. At 45 DAS, plants of similar height and foliar area were transplanted with roots to plastic bags containing $5 \mathrm{~L}$ of sterile growth substrate. At this stage 16 replications per treatment were used, with a total of 48 plants. At the beginning of flowering (90 DAS) and fruiting (216 DAS) the agronomic variables and fungal and substrate chemical parameters were determined from eight replications of each treatment.

Agronomic variables. a) number of leaves; b) foliar area $\left(\mathrm{cm}^{2}\right)$ using a digital image analyzer; c) plant fresh weight; d) root and foliar dry weight (leaves, stalks) using a air oven at $70{ }^{\circ} \mathrm{C}$ for $48 \mathrm{~h}$ until reaching a constant weight; e) shoot/root ratio (T/R); and f) root length, using the line intercept method (Newman, 1966).

Fungal parameters. a) AMF colonization percentage in the roots after trypan blue staining (Phillips and Hayman,

Table 1. Chemical parameters in an Ultisol under greenhouse conditions, inoculated with native (IN) and commercial (IC) arbuscular mycorrhizal fungi, and non-inoculated control (-I), in flowering and fruiting stage.

\begin{tabular}{|c|c|c|c|c|c|c|}
\hline \multirow[b]{2}{*}{ Parameters } & \multicolumn{3}{|c|}{ Flowering } & \multicolumn{3}{|c|}{ Fruiting } \\
\hline & $-I$ & IC & IN & $-\mathrm{I}$ & IC & IN \\
\hline $\mathrm{pH}$ & $5.65 \mathrm{a}$ & $6.13 \mathrm{a}$ & $6.38 \mathrm{a}$ & $5.25 \mathrm{a}$ & $5.28 \mathrm{a}$ & $5.55 \mathrm{a}$ \\
\hline MO, $\%$ & $8.29 a$ & $9.30 \mathrm{a}$ & $8.43 \mathrm{a}$ & $7.83 \mathrm{a}$ & $8.93 \mathrm{a}$ & $9.22 \mathrm{a}$ \\
\hline Available $\mathrm{P}, \mathrm{mg} \mathrm{kg}^{-1}$ & $3.05 b$ & $4.73 \mathrm{ab}$ & $6.29 \mathrm{a}$ & $2.60 \mathrm{a}$ & $2.16 \mathrm{ab}$ & $1.84 \mathrm{~b}$ \\
\hline P-ase, $\mathrm{mg} \mathrm{gsh}^{-1}$ & $0.75 \mathrm{a}$ & $0.71 \mathrm{a}$ & $0.79 \mathrm{a}$ & $1.51 \mathrm{a}$ & $1.41 \mathrm{a}$ & $1.29 b$ \\
\hline
\end{tabular}

Different letters for each parameter in flowering and fruiting indicate differences according to the Tukey test $(\mathrm{P}<0.05)$.

P-ase: phosphatase activity. 
1970); b) fungal mycelia using the methodology for soils, through extraction with glycerin acid and subsequent quantification by the line intercept method (Rubio et al., 2003); and c) number of spores by the wet sieving and sucrose gradient decanting method (Sieverding, 1991).

Chemical parameters and enzyme activity of the substrate. a) $\mathrm{pH}$ soil:water ratio $(1: 2.5)$; b) organic matter (OM, \%) with acid digestion with dichromate (Walkley and Black, 1934); c) available $\mathrm{P}$ through extraction with $\mathrm{NaHCO}_{3} 0.5 \mathrm{M}$ at $\mathrm{pH} 8.5$ (Olsen and Sommers, 1982), and soil acid phosphatase (E.C.3.1.3.2 orthophosphoricmonoester phosphohydrolase) was determined using $p$-nitrophenyl phosphate according to the procedure described by Tabatabai and Bremner (1969).

Plant height $(\mathrm{cm})$, from the base to the apex, was measured periodically from 15 DAS until harvest. The harvest was carried out at four timings between 170 and 216 DAS, using visual appreciation, as well evaluations of fruit quality.

Fruit parameters. a) number and fresh and dry weight $(\mathrm{g})$, length and diameter $(\mathrm{mm})$ of the fruit; b) length and diameter of the peduncle $(\mathrm{mm})$; c) total titulable acid (TTA) determined from ground pulp with a potentiometer until the final point 8.2 and expressed as a percentage of anhydride citric acid $100 \mathrm{~mL}^{-1}$ of juice (Tressler and Joslyn, 1961); d) $\mathrm{pH}$, with a potentiometer in drops of ground pulp; e) total soluble solids (TSS) with a refractometer $\left({ }^{\circ} \mathrm{Brix}\right)$, this commercial index considers all dissolved solids as sucrose; $\mathrm{f}$ ) maturity index, which is the ratio between sugar and acid $\left(\%{ }^{\circ} \mathrm{Brix} / \%\right.$ citric acid $)$ that expresses the sum of the citric, malic, oxalic and tartaric acids; g) ascorbic acid content (AA) by volumetry using the Tillman method based on the reduction of 2.6 dichlorophenol indophenol (Schmidt-Hebbel, 1981).

\section{Statistical analysis}

The data obtained were submitted to the Shapiro-Wilk (1965) normality test and then an ANOVA of one factor was carried out using the Tukey a posteriori multiple range means separation test $(\mathrm{P}<0.05)$. The Shapiro-Wilk test was used for data normalization for measurements of plant height, submitting them to repeated ANDEVA measurements over time, verifying sphericity through the Mauchly test, with correction of degrees of freedom by Greenhouse-Geisser test (1959). Finally the Tukey a posteriori multiple range means separation test was applied $(\mathrm{P}<0.05)$. Lineal Pearson correlations were carried out among some agronomic, fungal and substrate variables $(\mathrm{P}<0.05)$. SPSS software for Windows version 15.0 was used for processing the information.

\section{RESULTS AND DISCUSSION}

Of the chemical soil parameters measured at the flowering and fruiting stages (Table 1), soil $\mathrm{pH}$ did not present significant differences among the treatments, but was important for the development of fungal propagules given that it was significantly related to the number of spores in the soil $(\mathrm{r}=0.52 ; \mathrm{P}<0.05)$. In this respect, Friberg (2001) reported that $\mathrm{pH}$ influences the capacity of some AMF species to colonize roots. A low quantity of available $\mathrm{P}$ was found in the substrate at flowering, which decreased even more at fruiting because no nutritive solution was added. Ultisols are characterized by a low availability of $\mathrm{P}$ and in agricultural soils $\mathrm{P}$ is potentially available for plants depending on the soil-root environment, such as phosphatase enzymes (Borie et al., 1989). This parameter presented differences at fruiting, with the control and the IC treatment showing higher contents. On the other hand, high $\mathrm{P}$ content in the soil can inhibit the formation of AM symbiosis owing to a reduction in the development of external mycelia.

Mycorrhizal inoculation increased the growth rate of the plant measured as height, which in the IN treatment increased rapidly until 90 DAS (Figure 1A), while in the control and $G$. intraradices treatments plant height remained almost constant until fruiting. Significant differences were found at 216 DAS in the measurements between IN and (-I), the IN treatments registering the greatest height, with an average of $66.5 \mathrm{~cm}, 15.2 \%$ higher than IC $(57.7 \mathrm{~cm})$ and $30.8 \%$ higher than the control $(50.8$ $\mathrm{cm})$. These findings correspond to literature reports with other plants (Ouahmane et al., 2007).

At flowering, the foliar area of the plants inoculated with G. claroideum increased significantly, by $160 \%$ more than the control and 59\% more than in the G. intraradices treatment (Figura 1B).

According to Román (2003) the leave number and size in a pepper crop play an important role in that they determine future yield. The pepper plants inoculated with G. claroideum at 33 and 50 DAS had the highest number of leaves (4.4 and 5.6 leaves plant ${ }^{-1}$, respectively) followed by the control ( 4.2 and 5.3 leaves plant $\left.{ }^{-1}\right)$, while the IC treatment showed the lowest number (3.9 and 4.9 leaves plant $\left.^{-1}\right)$. These results coincide with what was reported by Román (2003) with pepper plants grown in greenhouses.

At flowering, the dry weight of the plants inoculated with the two morphotypes (Figure 2A) was significantly greater than that of the plants without inoculation, which indicates a better supporting of the transplanting stress. The weight of the IC plants increased by $60 \%$, while the IN plants increased by $116 \%$ in comparison to the control. At harvest, the IN showed even greater differences, with a $217 \%$ increase in comparison to the control. These effects 

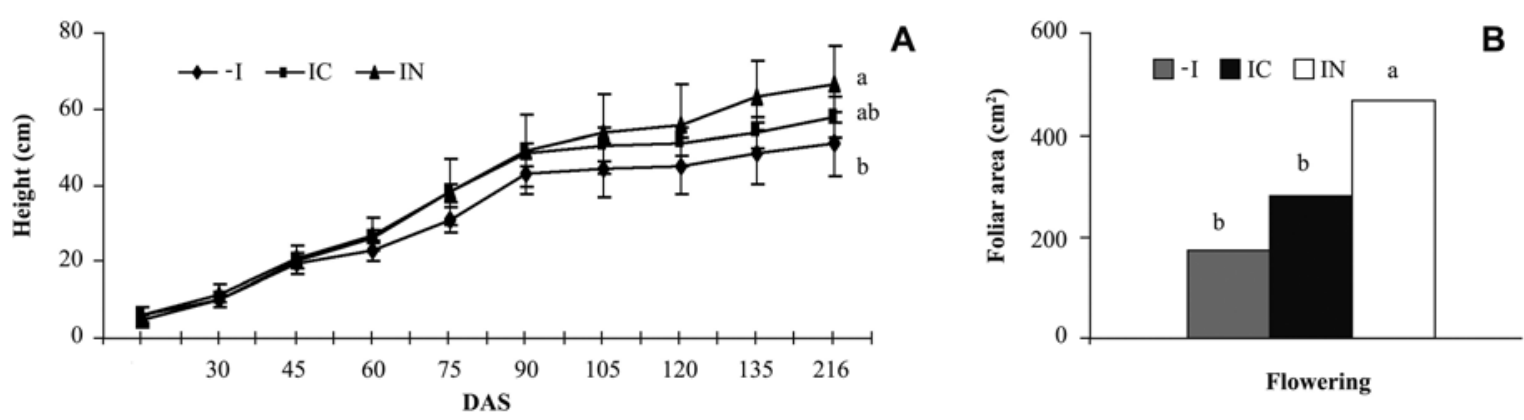

Different letters in each parameter indicate significant differences according to the Tukey test $(\mathrm{P}<0.05)$.

Figure 1. Effect of inoculation with native (IN) and commercial (IC) arbuscular mycorrhizal fungi and non-inoculated control (-I) in an Ultisol under greenhouse conditions: A) plant height over time (days after sowing, DAS) and B) foliar area at flowering.

are greater than those reported by Waterer and Coltman (1989) and Gaur et al. (1998), who, working with pepper plants, obtained yield increases of $112 \%$ in a soil inoculated with $G$. intraradices. On the other hand, at physiological maturity the plants inoculated with IC decreased notably in weight. Having significantly increased the vegetative growth of the plant, the native inoculants, composed of G. claroideum, showed great compatibility with the local ecotype of our chili pepper. According to Davies et al. (2000) it is important to select native and adapted AMF strains to achieve a higher yield.

The shoot/root ratio $(\mathrm{S} / \mathrm{R})$ was higher at flowering than at fruiting, a stage when the plants show evident signs of senescence, such as the fall of old leaves, that
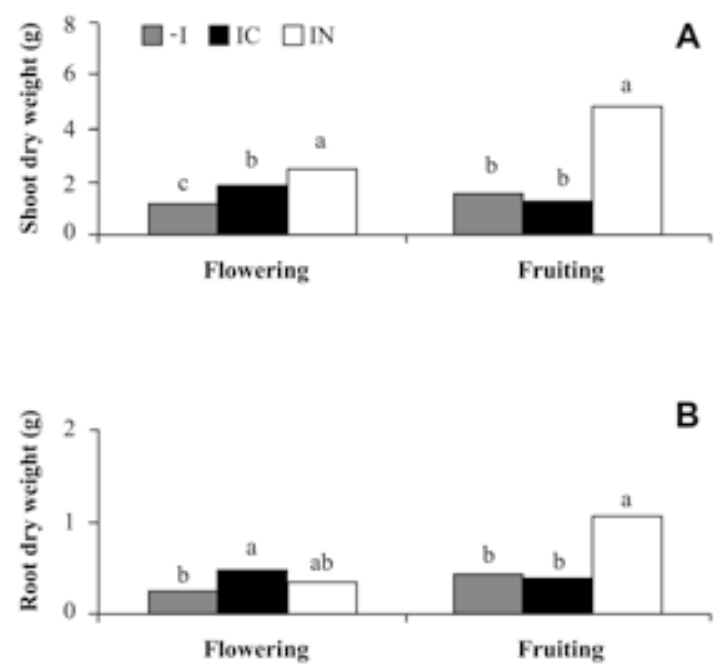

consequently reduce the quantity of dry matter. The production of biomass is linked to the phenology of the plant, mainly during flowering and fruiting. In these phases the plant invests similar quantities of photoassimilates for the production of fruit and the vegetative part; at the beginning of fruiting, vegetative growth is limited, with the fruit presenting the highest growth rates. At these two phenological stages, the IN treatment had the highest S/ $\mathrm{R}$ ratio, followed by -I and IC (Figure $2 \mathrm{C}$ ). A high $\mathrm{S} / \mathrm{R}$ ratio reflects a high degree of mycorrhizal effectiveness (Tobar et al., 1999), G. claroideum being more effective to promote growth of pepper plants than $G$. intraradices. In comparison to the non-inoculated control, the plants colonized by native AMF improved their vigor, robustness,
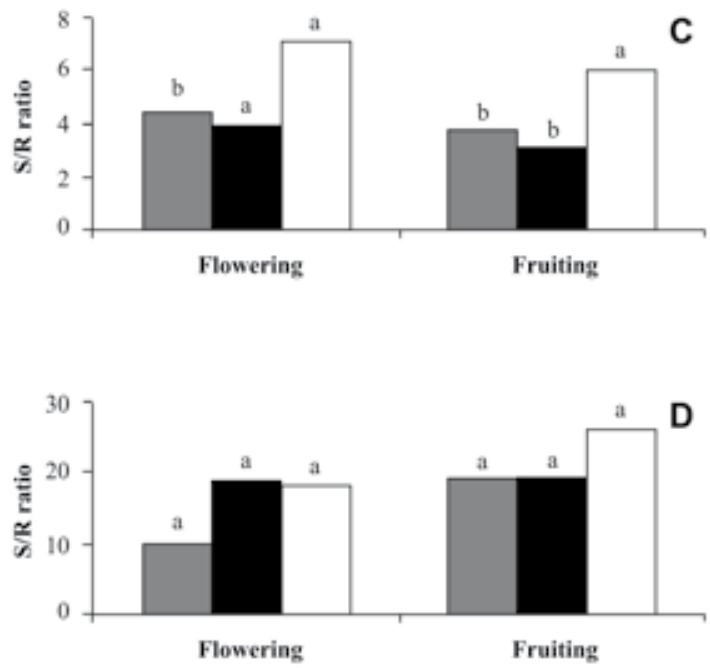

Different letters in each parameter indicate significant differences according to the Tukey test $(\mathrm{P}<0.05)$.

Figure 2. Pepper crop inoculated with native (IN) and commercial (IC) arbuscular mycorrhizal fungi and non-inoculated control (-I) in an Ultisol under greenhouse conditions. A) Shoot dry weight; B) root dry weight; C) shoot/root ratio; and $D)$ root length, in flowering and fruiting. 
development and consequently, their yield more. This beneficial effect of endomychorriza on horticultural crops was also reported by Aguilera-Gómez et al. (1999) in peppers inoculated with $G$. intraradices, obtaining a higher number of leaves, foliar area, shoot and yield. Root length was not different between the two inoculated treatments, but with the control at flowering, which did not exceed 10 $\mathrm{m}$ (Figure 2D). The capacity of the seedlings to overcome the transplanting shock depends on the capacity of the roots to support structural and functional changes, to the absorption of water and nutrients as well as the capacity of regeneration of new roots (Montaño-Mata and Núñez, 2003).

At 90 DAS, in the two inoculated treatments the colonization of the pepper plant roots was low in comparison to other vegetable crops in the region (Rubio et al., 1994; 1997), fluctuating between $2.4 \%$ and $7.4 \%$. Colonization with $G$. claroideum was significantly greater than with $G$. intraradices, differences that disappeared at physiological maturity (Figure 3A). High infectiveness does not always guarantee an improvement in plant growth; thus, beneficial responses have been reported with only $0.4 \%$ of AMF colonization (Carpio et al., 2005).

At flowering and fruiting IN plant at the highest number of AMF spores, with significant differences in comparison to the IC treatment and the control (Figure 3B). At harvest, the density of spores of G. claroideum in the substrate increased by $950 \%$ in comparison to the $G$. intraradices treatment. Producing fungus-plant compatibility avoids the problem of "parasitism" in the development of the symbioses (Rodríguez et al., 2004). There were a low number of spores in the control at 90 DAS, probably because of the presence of mycorrhizal propagules that resisted the sterilizing conditions of the substrate, thus being subsequently reproduced by the presence of a compatible host.

The color of the fruit originates from the plastids contained in the mesocarp, which are green at physiological immaturity because of the presence of chlorophyll, and in the mature stage change to red. In this last stage the chlorophyll and the anthocyanin degrade and the chloroplasts are transformed into chromoplasts, which contain carotenoids that are responsible for the final yellow-red color (Popovsky and Paran, 2000; Méndez et al., 2004). The velocity of fruit development or the anthesis-maturation time (Gómez, 2000) was different for the two AMF inoculants. The treatment that showed greater precocity of production was IN, with the first harvest at 167 DAS and with $64 \%$ of the fruit matured, while the control had only $18 \%$ of fruit matured, while in IC the fruit, still remained immature. At 189 DAS the same percentage of fruits had matured in both inoculated treatments $(18 \%)$ finalizing the phenological
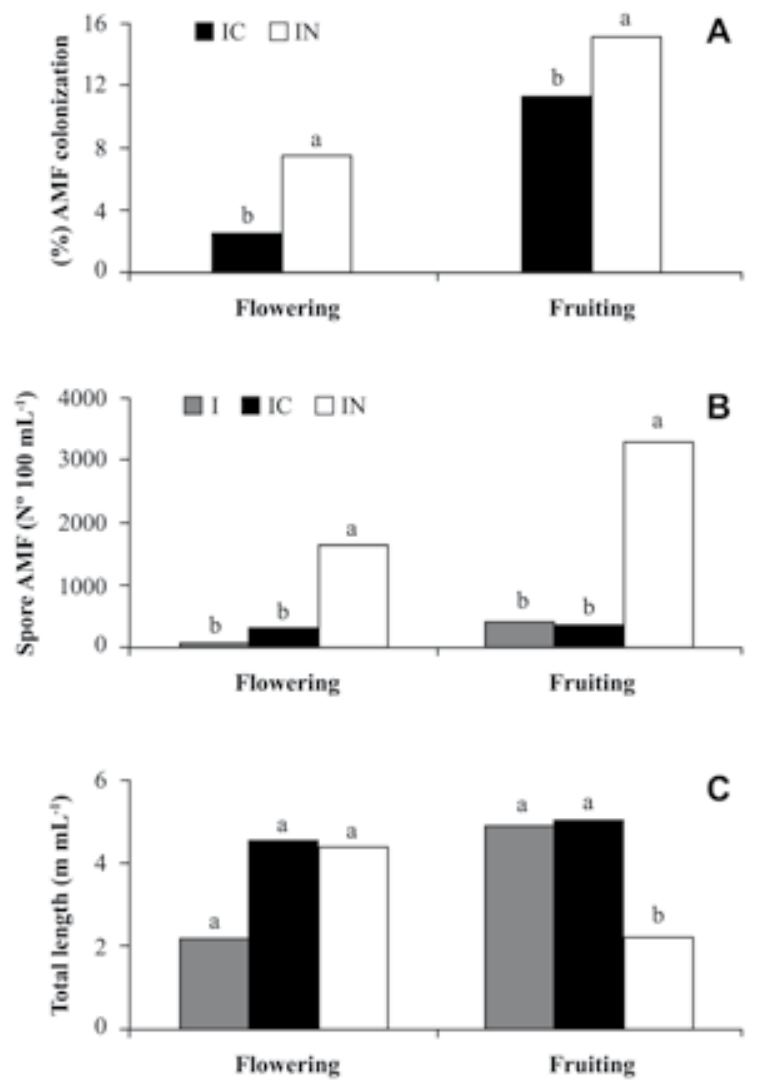

Different letters in each parameter indicate significant differences according to the Tukey test $(\mathrm{P}<0.05)$.

Figure 3. Fungal parameters of pepper crop after inoculation with native (IN) and commercial (IC) arbuscular mycorrhizal fungi (AMF) and noninoculated control (-I) in an Ultisol under greenhouse conditions. A) Percentage of AMF colonization; B) spore number; and C) total hyphae length at flowering

stage for the IN treatment at 203 DAS, while the last harvest for the other treatments was concluded at 216 DAS. The inoculation with IN shortened the maturation process by 22 days, providing an attractive advantage for the cultivation of this vegetable. This acceleration in the velocity of development is possibly achieved because of the compatibility between G. claroideum and the local ecotype of chili pepper that grew in an Ultisol (Table 2). Thus, G. claroideum had a beneficial effect for the plants and although it proved not to be very infective, its behavior was very effective, given the high correlation obtained between fruit weight and plant weight $(\mathrm{r}=0.79$; $\mathrm{n}=24 ; \mathrm{P}<0.05)$. These results show the importance of achieving a better association between a determined AMF strain and the ecotype of pepper, in order to improve and optimize the production process. 
Table 2. Quality parameters of "Cacho de cabra" chili pepper fruits in an Ultisol under greenhouse conditions inoculated with native (IN) and commercial (IC) arbuscular mycorrhizal fungi and non-inoculated control (-I).

\begin{tabular}{|c|c|c|c|}
\hline \multirow[b]{2}{*}{ Parameters of quality of the fruit } & \multicolumn{3}{|c|}{ Treatments } \\
\hline & $-\mathbf{I}$ & IC & IN \\
\hline $\mathrm{N}^{\mathrm{o}}$ fruit per plant & $1.0 \mathrm{~b}$ & $1.0 \mathrm{~b}$ & $2.3 \mathrm{a}$ \\
\hline Fresh weight, $g$ & $4.9 b$ & $3.6 \mathrm{~b}$ & $13.5 \mathrm{a}$ \\
\hline Dry weight, $g$ & $0.7 b$ & $0.4 \mathrm{~b}$ & $2.3 \mathrm{a}$ \\
\hline Length, mm & $75.8 b$ & $96.2 b$ & $158.2 \mathrm{a}$ \\
\hline Widest diameter, $\mathrm{mm}$ & $13.5 b$ & $10.6 \mathrm{~b}$ & $18.0 \mathrm{a}$ \\
\hline Peduncle diameter, $\mathrm{mm}$ & $4.5 \mathrm{~b}$ & $4.4 b$ & $6.5 \mathrm{a}$ \\
\hline Peduncle length, mm & $32.5 \mathrm{a}$ & $32.5 \mathrm{a}$ & $36.0 \mathrm{a}$ \\
\hline Ascorbic acid, g citric acid $100 \mathrm{~mL}^{-1}$ & $319.0 \mathrm{a}$ & $298.0 \mathrm{ab}$ & $294.0 \mathrm{~b}$ \\
\hline $\mathrm{pH}$ & $5.33 \mathrm{ab}$ & $5.69 \mathrm{a}$ & $5.19 b$ \\
\hline Total titulable acidity (TTA) & $20.0 \mathrm{a}$ & $15.6 \mathrm{a}$ & $22.8 \mathrm{a}$ \\
\hline Total soluble solids, ${ }^{\circ}$ Brix & $11.8 \mathrm{a}$ & $9.7 \mathrm{a}$ & $11.5 \mathrm{a}$ \\
\hline Maturity ratio, ${ }^{\circ} \mathrm{Brix} / \%$ TTA & $0.5 \mathrm{a}$ & $0.7 \mathrm{a}$ & $0.5 \mathrm{a}$ \\
\hline
\end{tabular}

Different letters in each parameter indicate significant differences according to the Tukey test $(\mathrm{P}<0.05)$.

The parameter evaluated for fruit quality, such as weight, length, diameter and peduncle diameter, were significantly higher in the IN treatment, while no differences were found between the IC treatment and the control (Table 2). Fresh weight of fruits in IN increased in comparison to the control and the IC by $177 \%$ and $272 \%$, and the length by $86 \%$ and $75 \%$, respectively. After transplanting, measurements taken at flowering showed differences among the IN, IC and the control in terms of the quantity of mycorrhizal propagules. According to what was reported by Román (2003) AMF colonization in pepper plants cultivated in greenhouses enhanced the number and fresh weight of fruits. The increase in fruit weight was greater in our experiment than that reported by Mena-Violante et al. (2006) in Capsicum annuum cv. "San Luis", where the inoculated treatments reached increases of $25 \%$ in comparison to the control without inoculants.

In this experiment the inoculation with $G$. intraradices did not improve yield or quality of chili peppers. The majority of commercial inoculants contain G. intraradices, which has been considered as a "super strain" and "generalist" because it is highly infective for a wide range of cultivars (Vosatka and Dodd, 2002). It may be that, in this study the differences obtained in response between the two inoculants were caused by the adaptability of G. claroideum to local conditions. Sensoy et al. (2007) observed that in eight pepper genotypes inoculated with G. intraradices and Gigaspora margarita, five cultivars had greater dry weight while three obtained yields similar to plants without inoculation. There is some evidence that the AMF strains are positive influencing plant growth under the same condition as those from where they were originally isolated (Vosatka and Dodd, 2002).

During the maturation process the fruit pulp had high sugar content, due to starch production that transforms into sugars; nevertheless, the native and commercial AMF inoculations did not produce differences in the fruit in relation to the control. Another parameter, the TAA, is a sensitive indicator of quality during the transport and storing of the vegetables because it is highly vulnerable to chemical and enzymatic oxidation and solubility in water (Martins and Silva, 2004), fluctuated between 294 and 319 g $100 \mathrm{~mL}^{-1}$, with differences between IN and the control. With regard to the TTA, which is a property perceptible by consumers, no differences among the treatments were found. The low $\mathrm{pH}$ of the fruits originates from organic acids formed in tissue vacuoles (González et al., 2001) and fluctuated between 5.19 and 5.69. Fruit of the treatments inoculated with native AMF were significantly more acidic, so that consumer would prefer them.

At flowering higher yields of the plants were obtained with IN, related to greater AMF colonization in the roots which increased substantially at fruiting, achieving larger fruit, higher weight and better quality than that obtained with IC. The results show the positive effect in the growth and development of local ecotypes of chili peppers, as well as the quality of the fruit when an appropriate selection is made of the mycorrhizal fungus for inoculation, corroborating what was reported by Llonín and Medina (2002). From these results it appears necessary to carry out another tests comparing native AMF prior to mass inoculum production for inoculation of vegetable crops that require nursery or greenhouse cultivation. 


\section{CONCLUSIONS}

Under the test conditions, the inoculation of a substrate with a native AMF inoculant, Glomus claroideum, in comparison to a commercial inoculant, Glomus intraradices, positively affected the production of "Cacho de cabra" chili pepper, resulting in more vigorous plants with a higher foliar area and shoot/root ratio, which accelerated fruiting and improved quality, and led to greater quantity of fungal propagules in the soil. These results once again show the importance of using native local and autochthonous AMF strains as biofertiilzers that are better adapted to the regional edaphoclimatic conditions and can therefore be expected to be of greater nutritional benefit to regional plants varieties which are often grown in organic farming systems.

\section{ACKNOWLEDGEMENTS}

The authors wish to thank the projects FONDECYT $\mathrm{N}^{\circ} 1070283$ and DGIUCT $\mathrm{N}^{\circ} 2006-3-02$ for the funding provided for carrying out this research.

\section{RESUMEN}

Efecto de los hongos micorrícicos arbusculares en un cultivo ecológico de ají (Capsicum annuum L.) cacho de cabra. En el sur de Chile, agricultores mapuches han cultivado durante décadas ecotipos locales de ají (Capsicum annuиm L.) "Cacho de cabra" para elaborar "merkén", producto con reconocidas ventajas en el mercado internacional. Esta hortaliza requiere etapa de almácigo, pudiendo beneficiarse nutricionalmente con la asociación simbiótica del tipo micorrizas, logrando una mejor adaptación al trasplante. Los hongos micorrícicos arbusculares son biótrofos obligados abundantes en agrosistemas con manejo conservacionista. El objetivo de este estudio fue comparar, en invernadero, el efecto de la inoculación de dos hongos, uno comercial, Glomus intraradices (IC), y otro nativo, Glomus claroideum (IN), con un testigo sin inoculación (-I) sobre la producción y calidad de ají "Cacho de cabra". A los 45 días después de la siembra (DDS) se realizó el trasplante y a los 90 y 216 DAS se evaluaron parámetros de calidad del fruto, fúngicos y edáficos. La cosecha fue escalonada en cuatro etapas. Con la inoculación de IN se obtuvieron plantas de mayor altura y área foliar que mostraron mayor velocidad de desarrollo del fruto adelantándose la cosecha en 49 días y con aumentos en el peso fresco de $177 \%$ en relación al control. La colonización en las raíces de ají fue baja con diferencias significativas entre IN e IC, mientras que una gran cantidad de esporas permaneció en el sustrato. Se concluye que la inoculación con hongos nativos disminuyó el estrés del trasplante acelerando la maduración del ají con aumento de producción y calidad.

Palabras clave: micorriza, inoculante, biofertilizantes, calidad fruto, hortalizas.

\section{LITERATURE CITED}

Aguilera-Gomez, L., F.T. Davies Jr., S.A. Duray, L. Phavaphutanon, and V. Olalde-Portugal. 1999. Influence of phosphorus and endomycorrhiza (Glomus intraradices) on gas exchange and plant growth of chile ancho pepper (Capsicum annuum cv. San Luis). Photosynthetica 36:441-449.

Augé, R.M. 2004. Arbuscular mycorrhizae and soil/plant water relations. Can. J. Soil Sci. 84:373-381.

Azcón-Aguilar, C., M.C. Jaizme-Vega, and C. Calvet. 2002. The contribution of arbuscular mycorrhizal fungi to the control of soil-borne plant pathogen. $p$. 187-197. In Gianinazzi, S., H. Schüepp, J.M. Barea, and K. Haselwandter (eds.) Mycorrhizal technology in agriculture: From genes to bioproducts. Birkhäuser Verlag AG, Basel, Switzerland.

Borie,F.,H.Zunino, andL. Martínez. 1989. Macromolecule P-associations and inositol phosphates in some Chilean volcanic soils of temperate regions. Commun. Soil Sci. Plant Anal. 20:1881-1894.

Carpio, L.A., F.T. Davies, and M.A. Arnold. 2005. Arbuscular mycorrhizal fungi, organic and inorganic controlled-release fertilizers: Effect on growth and leachate of container-grown bush morning glory (Ipomoea carnea ssp. fistulosa) under high production temperatures. J. Amer. Soc. Hort. Sci. 130:131-139.

Corkidi, L., E.B. Allen, D. Merhaut, M. Allen, J. Downer, J. Bohn, and M. Evans. 2005. Effectiveness of commercial mycorrhizal inoculants on the growth of Liquidambar styraciflua in plant nursery conditions. J. Environ. Hort. 23:72-76.

Davies, F.T. Jr., J.A. Saraiva Grossi, L. Carpio, and A.A. Estrada-Luna. 2000. Colonization and growth effects of the mycorrhizal fungus Glomus intraradices in a commercial nursery container production system. J. Environ. Hort. 18:247-251.

Douds, D.D., G. Nagahashi Jr., P.E. Pfeffer, W.M. Kayser, and C. Reider. 2005. On-farm production and utilization of arbuscular mycorrhizal fungus inoculum. Can. J. Plant Sci. 85:15-21.

Evans, M. 1997. Mycorrhizal inoculation of California native plants in containers. Comb. Proc. Int. Plant Prop. Soc. 47:260-261 
Friberg, S. 2001. Distribution and diversity of arbuscular mycorrhizal fungi in traditional agriculture on the Niger inland delta, Mali, West Africa. CBM:s Skriftserie 3:53-80.

Gaur, A., A. Adholeya, and K. Mukerji. 1998. A comparison of AM fungi inoculants using Capsicum and Poliantes in marginal soil amended with organic matter. Mycorrhiza 7:307-312.

Gómez, D. 2000. Estudio del crecimiento y desarrollo del fruto del tomate (Lycopersicon esculentum Mill.) en función del clima. 70 p. Tesis Ingeniero Agrónomo. Universidad Nacional de Colombia, Facultad de Agronomía, Bogota, Colombia.

González, V., M.S. Hernández, A. Herrera, J. Barrera, O. Martínez, y D. Pérez. 2001. Desarrollo del fruto e índices de cosecha de la carambola (Averrhoa carambola L.) producida en el piedemonte amazónico colombiano. Agronomía Colombiana 18(1-3):53-62.

Greenhouse, S.W., and S. Geisser. 1959. On methods in the analysis of profile data. Psychometrika 55: 431433.

Jaizme-Vega, M.C., y A.S. Rodríguez-Romero. 2004. Uso de micorrizas en banano: logros y perspectivas. p. 143160. Publicación especial. XVI Reunión Internacional ACORBAT, Oaxaca, México.

Linderman, R.G., and E.A. Davis. 2004. Varied response of marigold (Tagetes spp.) genotypes to inoculation with different arbuscular mycorrhizal fungi. Sci. Hortic. (Canterbury, Engl.) 99:67-78.

Llonín, D., y N. Medina. 2002. Nutrición mineral con N, $\mathrm{P}$ y K en la simbiosis hongos micorrizógenos-tomate (Lycopersicon esculentum Mill.) en Ferralsol. Cultivos Tropicales 23(4):83-88.

Martins, R.C., and C.L.M. Silva. 2004. Green beans (Phaseolus vulgaris L.) quality loss upon thawing. J. Food Engin. 65:37-48.

Mena-Violante, H.G., O. Ocampo-Jiménez, L. Dendooven, G. Martínez-Soto, J. González-Castañeda, F.T. Davies Jr., and V. Olalde-Portugal. 2006. Arbuscular mycorrhizal fungi enhance fruit growth and quality of chile ancho (Capsicum annuum L.) plants exposed to drought. Mycorrhiza 16:261-267.

Méndez, M.A., G.A. Ligarreto, M.S. Hernández, y L.M. Melgarejo. 2004. Evaluación del crecimiento y determinación de índices de cosecha en frutos de cuatro materiales de ají (Capsicum sp.) cultivados en la Amazonia colombiana. Agronomía Colombiana 22(1):7-17.

Montaño-Mata, N.J., y J.C. Núñez. 2003. Evaluación del efecto de la edad de trasplante sobre el rendimiento en tres selecciones de ají dulce Capsicum chinense Jacq. en Jusepín, estado Monagas. Rev. Fac. Agron. (LUZ) 20:144-155.
Newman, E.I. 1966. A method of estimating the total root length in a simple. J. Appl. Ecol. 3:139-145.

Olsen, S.R., and L.E. Sommers. 1982. Phosphorus. p. 403-430. In A.L. Page et al. (eds.) Methods of soil analysis. Part 2. $2^{\text {nd }}$ ed. Agron. Monogr. 9. ASA and SSSA, Madison, Wisconsin, USA.

Ouahmane, L., J. Thioulouse, M. Hafidi, Y. Prin, M. Ducousso, A. Galiana, et al. 2007. Soil functional diversity and $\mathrm{P}$ solubilization from rock phosphate after inoculation with native or allochtonous arbuscular mycorrhizal fungi. For. Ecol. Manage. 241:200-208.

Phillips, J.M., and D.S. Hayman. 1970. Improved procedure for cleaning roots and staining parasitic and vesicular-arbuscular mycorrhizal fungi for rapid assessment of infection. Trans. Br. Mycol. Soc. 55:158-161.

Popovsky, S., and I. Paran. 2000. Molecular genetics of the locus in pepper, its relation to capsanthin-capsorubin synthase and to fruit color. Theor. Appl. Genet. 101(12):86-89.

Rodríguez, Y., B. de la Noval, F. Fernández, y P. Rodríguez. 2004. Estudio comparativo del comportamiento de seis cepas de hongos micorrícicos arbusculares en su interacción con el tomate (Lycopersicon esculentum Mill. var. Amalia). Ecología Aplicada 3(1 y 2):162171.

Román, F. 2003. Concentración de reguladores del desarrollo vegetal inducida por hongos endomicorrízicos en dos cultivares de Chile (Capsicum annuum L.). 121 p. Tesis Doctor en Ciencias. Universidad de Colima, Tecomán, México.

Rubio, R., F. Borie, C. Schalchli, C. Castillo, and R. Azcón. 2003. Occurrence and effect of arbuscular mycorrhizal propagules in wheat as affected by the source and amount of phosphorus fertilizer and fungal inoculation. Appl. Soil Ecol. 23:245-255.

Rubio, R., M. Cepeda, F. Borie, y A. Contreras. 1997. Efecto de hongos micorrizógenos arbusculares sobre el crecimiento de algunas hortalizas sobre el crecimiento de algunas hortalizas en almácigo y posterior trasplante. Agric. Téc. (Chile) 57:161-168.

Rubio, R., R. Uribe, F. Borie, E. Moraga, y A. Contreras. 1994. Micorrizas VA en horticultura. Velocidad de infección en lechuga y tomate y su incidencia sobre el desarrollo del cultivo. Agric. Téc. (Chile) 54:7-14.

Schmidt-Hebbel, H. 1981. Avances en ciencia y tecnología de los alimentos. Ed. Alfabeta Impresores colaboración Merck Química Chilena, Santiago, Chile.

Sensoy, S., S. Demir, O. Turkmen, C. Erdinc, and O.O. Savur. 2007. Responses of some different pepper (Capsicum annuum L.) genotypes to inoculation with two different arbuscular mycorrhizal fungi. Sci. Hortic. (Canterbury, Engl.) 113:92-95. 
Shapiro, S.S., and M.B. Wilk. 1965. An analysis of variance test for normality. Biometrika 52:591-9.

Sieverding, E. 1991. Vesicular-arbuscular mycorrhiza management in tropical agrosystems. $371 \mathrm{p}$. Deutsche Gesellschaft für Technische Zusammenarbeit (GTZ) $\mathrm{GmbH}$, Eschborn, Germany.

Souchie, E.L., R. Azcón, J.M. Barea, O.J. SagginJúnior, and E.M. Ribeiro da Silva. 2006. Phosphate solubilizing and arbuscular mycorrhizal fungi. Pesq. Agropec. Bras. 41(9):1405-1411.

Tabatabai, M.A., and J.M. Bremner. 1969. Use of $p$ nitrophenyl phosphate for assay of soil phosphatase activity. Soil Biol. Biochem. 1:301-307.

Tobar, R.M., R. Azcón, and J.M. Barea. 1999. The improvement of plant $\mathrm{N}$ acquisition from an ammonium treated drought-stressed soil by the fungal symbiont in arbuscular mycorrhizae. Soil Biol. Fert. 9:1-8.

Tressler, D., and M. Joslyn. 1961. Fruits and vegetables juice-processing technology. 1028 p. AVI Publishing, Wetsport, Connecticut, USA. von Alten, H., B. Blal, J.C. Dodd, F. Feldman, and M. Vosatka. 2002. Quality control of arbuscular mycorrhizal fungi inoculum in Europe. p. 281-296. In Gianinazzi, S., H. Schüepp, J.M. Barea, and K. Haselwandter (eds.) Mycorrhizal technology in agriculture: From genes to bioproducts. Birkhäuser Verlag AG, Basel, Switzerland.

Vosatka, M., and J.C. Dodd. 2002. Ecological considerations for successful application of arbuscular mycorrhizal fungi inoculum. p. 235-247. In Gianinazzi, S., H. Schüepp, J.M. Barea, and K. Haselwandter (eds.) Mycorrhizal technology in agriculture: From genes to bioproducts. Birkhäuser Verlag AG, Basel, Switzerland.

Walkley, A., and Y.A. Black. 1934. An examination of the Detjareff method for determining soil-organic matter and a proposed modification on techromic acid titration methods. Soil Sci. 37:29-38.

Waterer, D., and R. Coltman. 1989. Mycorrhizal infection level of bell pepper transplants influences subsequent responses to soil solutions phosphorus. J. Plant Nutr. 12:327-340. 